\title{
"Flagging the Lines": Basque immigrant sheepherders and the early US Forest Administration in Nevada, 1890-1920
}

\author{
IKER SAITUA
}

KEYWORDS: Basque immigrant sheepherders, Western History, US Forest Service, livestock raising in Nevada.

JEL CODES: J61, Q15, Q28, Q34.

$I$ $n$ the early twentieth century, the US Forest Service began to exclude itinerant sheep operations from the public-domain lands it administered: the National voted to grazing were not regulated. To some local ranchers and stockmen, the increasing presence of itinerant sheepherders, including Basque immigrants, represented the first of a growing number of competitors on Nevada's public-domain lands. These stockmen blamed itinerant sheepherders for all the problems affecting the water and grassland ecosystems, such as the deterioration of the ranges and the fouling of springs and streams. Their representatives requested an expansion of National Forest boundaries as a means of asserting exclusive use of the range for stockmen. Although at first the Forest Service keenly appreciated the problems of local stock raisers, it opposed the idea of expanding the National Forests in Nevada solely for the purpose of range control. This article explores how some ranchers advocated expanding the National Forest lands within the State of Nevada as a strategy to protect their economic interests and force itinerant sheepherders out of business. 


\section{«Marcando las líneas»: pastores inmigrantes vascos y la administración temprana del Servicio Forestal de los Estados Unidos en Nevada, 1890-1920}

\section{PALABRAS CLAVE: pastores inmigrantes vascos, historia del Oeste norteamericano, Servicio Forestal de los Estados Unidos, ganadería en Nevada.}

\section{CÓDIGOS JEL: J61, Q15, Q28, Q34.}

$1 \begin{aligned} & \text { comienzos del siglo Xx, el Servicio Forestal de los Estados Unidos comenzó a } \\ & \text { excluir a las operaciones ovinas itinerantes de las tierras del dominio público } \\ & \text { que administraba: los bosques nacionales. Pero fuera de estos bosques, las ex- }\end{aligned}$ tensas tierras de dominio público dedicadas al pastoreo no estaban reguladas. Para algunos rancheros y ganaderos locales, la creciente presencia de pastores itinerantes, incluyendo a los inmigrantes vascos, representaba el primero de un número creciente de competidores en las tierras de dominio público en Nevada. Estos ganaderos culpaban a los pastores itinerantes de ovejas por causar todos los problemas que afectaban a los ecosistemas de agua y pastizal (deterioro de los prados y contaminación de manantiales y arroyos). Solicitaron a través de sus representantes expandir los límites de los bosques nacionales como un medio para adquirir el derecho exclusivo de uso de las praderas. Aunque en un primer momento el Servicio Forestal se mostró favorable a esta propuesta, finalmente rechazó la idea de expandir los bosques nacionales en Nevada con el único fin de controlar las praderas. Este artículo explora cómo algunos rancheros defendieron la expansión de las tierras de los bosques nacionales en el estado de Nevada como una estrategia para proteger sus intereses económicos y forzar a esos transeúntes a abandonar el negocio de la cría de ovejas.

Received: 2016-11-15 - Revised: 2017-11-15 - Accepted: 2017-12-12

Iker Saitua [orcid.org/0000-0002-8367-7070] is a Basque Government Postdoctoral Fellow in History at the University of California, Riverside and University of the Basque Country (UPV/EHU). Address: University of California, Riverside, 900 University Avenue, HMNSS 1212 History, Riverside, CA 92521 (United States of America).Email: isaitua@ucr.edu 


\section{INTRODUCTION}

On March 11, 1909, attorney Charles Belknap Henderson, member of the Henderson Banking Company of Elko (Nevada) ${ }^{1}$, wrote a letter to US Senator Francis G. Newlands of Nevada, urging him to support the decisions of the local Forest Service office in granting a limited number of permits in the Humboldt National Forest ${ }^{2}$. Henderson noted to Newlands that applications for permits to graze over five hundred thousand head of sheep and over twenty thousand head of cattle were received by the National Forest. Officials, however, denied over two hundred thousand head of sheep. Henderson explained the situation as follows:

The rejected applications were those of Basks [sic. -Basques] and foreigners who were not citizens, or had only taken out their first papers, and who owned no land in or adjoining the Reserve... There is no question but that the local office acted fair in the allotment and took the proper step to protect the Reserve. To have allowed five hundred thousand sheep to go in the Reserve would have injured it to such an extent that it would have taken a number of years to get it back into the condition that it is now in ${ }^{3}$.

As a prominent member of the local financial community, Henderson appeared supportive of Forest Service policy based on the three-tier permit preference system, which granted grazing preferences to those established stock owners who traditionally grazed stock on land which after 1905 became National Forests. He was in total agreement with this grazing system that aimed at favoring those who had stronger ties to the local community and who were probably either clients of his bank or potential customers, by keeping many of the itinerant sheepherders out of the National Forest ranges. Among these undesirables, and despite the obvious misspelling, Henderson explicitly referred to Basque immigrant sheepherders as a group of landless and marginal peasants whose activities were detrimental to the public interest ${ }^{4}$. In the name of conservation, Henderson legitimized this federal authority over National Forest ranges and criminalized sheepherders, particularly Basque immigrants, who were seen as potential competitors for local ranch and stockmen.

1. DAVIS (1913: 634-37).

2. On Newlands' political career, see Rowley (1996).

3. Charles Belknap Henderson to Francis G. Newlands, March 11, 1909, Newlands Papers, Sterling Library, Yale University, New Haven, Connecticut.

4. Ibid. 
During the early twentieth century, as the US Congress and the President moved to establish forest reserves and eventually National Forests, issues of rangeland governance made the Basque itinerant sheepherders central to a political debate at the state and national level over who could use public grazing lands in Nevada. After 1905, while the US Forest Service had taken control of some parts of the grazing situation on the public-domain lands in Nevada, especially in the high mountain meadows, a vast open range still remained outside Forest Service management. While conservation policies were unfolding in this state, the growing disorder on the Nevada ranges often meant that contracted sheepherders, such as the Basques, bore the brunt of the resulting range conflicts.

By the turn of the century, the situation on Nevada's ranges desperately called for a more orderly system of range resource use. Both local ranchers and conservationists defended the idea that transient sheepherders were detrimental to agricultural development, permanent stock-raising and the public interest, based on a utilitarian conservation ethic. By framing Basque sheepherders as environmentally destructive, they justified their expulsion from the open ranges and urged federal regulation of grazing on the undisposed public domain in Nevada. Largely based on government records, this article examines how local established ranchers advocated expanding the National Forest lands within the state of Nevada, as a strategy to protect their economic interests and force those transient sheepmen out of business by invoking the utilitarian philosophy of resource conservation.

\section{NEVADA'S PROBLEMS WITH THE FREE AND OPEN RANGE}

After the American Civil War (1861-65), the livestock industry in the Intermountain West ranges developed with open-range grazing. Low operating expenses combined with cheap labor, free forage and open range made for large profits. The free and open range was owned by the federal government and failures prevented land transfers into the hands of private ownership under federal land alienation laws. The result was the continued ownership of much of the American West and almost all of Nevada by the federal government. What land was acquired privately resulted in the monopolization of water sources and rangelands by large livestock operations. Local customs and practices in the claiming and use of water did not confer rights to the range itself, although they helped to secure access to the range by excluding others (Adams, 1916: 324-33) ${ }^{5}$.

5. On community grazing in the American West, see EASTMAN and GRAY (1987) and BADEN and SNOw (1997). 
In the spring of 1869, the Central Pacific Railroad completed its route across Nevada. The railroad opened new markets, or at least set the stage for market access for livestock raised on Nevada ranges. During the 1870s, because sheep products were more valued in Chicago and other far away markets on the East Coast, the development and improvement of transportation and favorable market conditions made Nevada a perfect state to raise large sheep herds ${ }^{6}$. Thus, as in the Great Plains, some large livestock operations had expanded to a point where they neglected to grow winter feed for the numbers of stock on the rangelands. By the late 1880s, however, severe droughts and cold winters demanded a transformation of open-range grazing practices that now required the cultivation of hay crops for winter feed stock (Young \& Sparks, 1985: 48-55; White, 1991: 270-72).

The winter of 1889-90 was the disastrous "White Winter" on Nevada ranges. After such an extreme-weather event, stock operators abandoned the classic open-range system and placed greater emphasis upon the raising of hay for winter-feeding. The White Winter significantly reduced cattle numbers on the Nevada ranges to the benefit of sheep graziers. Range scientist James Young writes: [...] the net immediate effect of the white winter was freedom for the range sheep industry to expand without competition from previously established cattle ranches. The exhaustion of perennial grasses was followed by the invasion of annuals, shrubs, and big sagebrush, all of which did not adversely affect sheep grazing. While smaller operations scrambled to pick up the pieces, the ranges were now open to outside herds, especially sheep (Young \& Sparks, 1985: 133-36).

In the 1890s, sheep ranching expanded rapidly in Nevada. In the years 1890-99, according to the agricultural census of 1900, the total sheep population in Nevada increased from 273,469 to 568,251 head, more than the total number of neat cattle (see Table 1$)^{7}$. Compared to cattle, sheep grazed and browsed more efficiently as new vegetation communities took over on the depleted ranges. Furthermore, sheep could utilize snow as a water source on Nevada's winter ranges (see Figure 1). The economic success of those sheep outfits depended largely upon the free use of public-domain lands, secure winter feed and water resources, and the employment of dependable low-wage agricultural labor (Rowley, 2000: 96-118; Young \& Sparks, 1985: 68).

6. For a discussion of how the city acted as a nucleus and prod for the countryside's often distant development in terms of agricultural crops or stock enterprises, see CRONON (1991).

7. Spring lambs were not reported here. 


\section{TABLE 1}

Total number of sheep and neat cattle in the state of Nevada, 1860-1900

\begin{tabular}{lrcccc}
\hline Nevada & $\mathbf{1 8 6 0}$ & $\mathbf{1 8 7 0}$ & $\mathbf{1 8 8 0}$ & $\mathbf{1 8 9 0}$ & $\mathbf{1 9 0 0}$ \\
\hline Total number of sheep & 376 & 11,018 & 280,695 & 273,469 & 568,251 \\
Total number of neat cattle & 5,471 & 31,516 & 216,823 & 210,900 & 304,131 \\
\hline
\end{tabular}

Source: Merriam (1902).

\section{FIGURE 1}

Traditional winter sheep ranges of the Intermountain region located in Nevada, southern Idaho, eastern and western Utah, and southwestern Wyoming, 1953

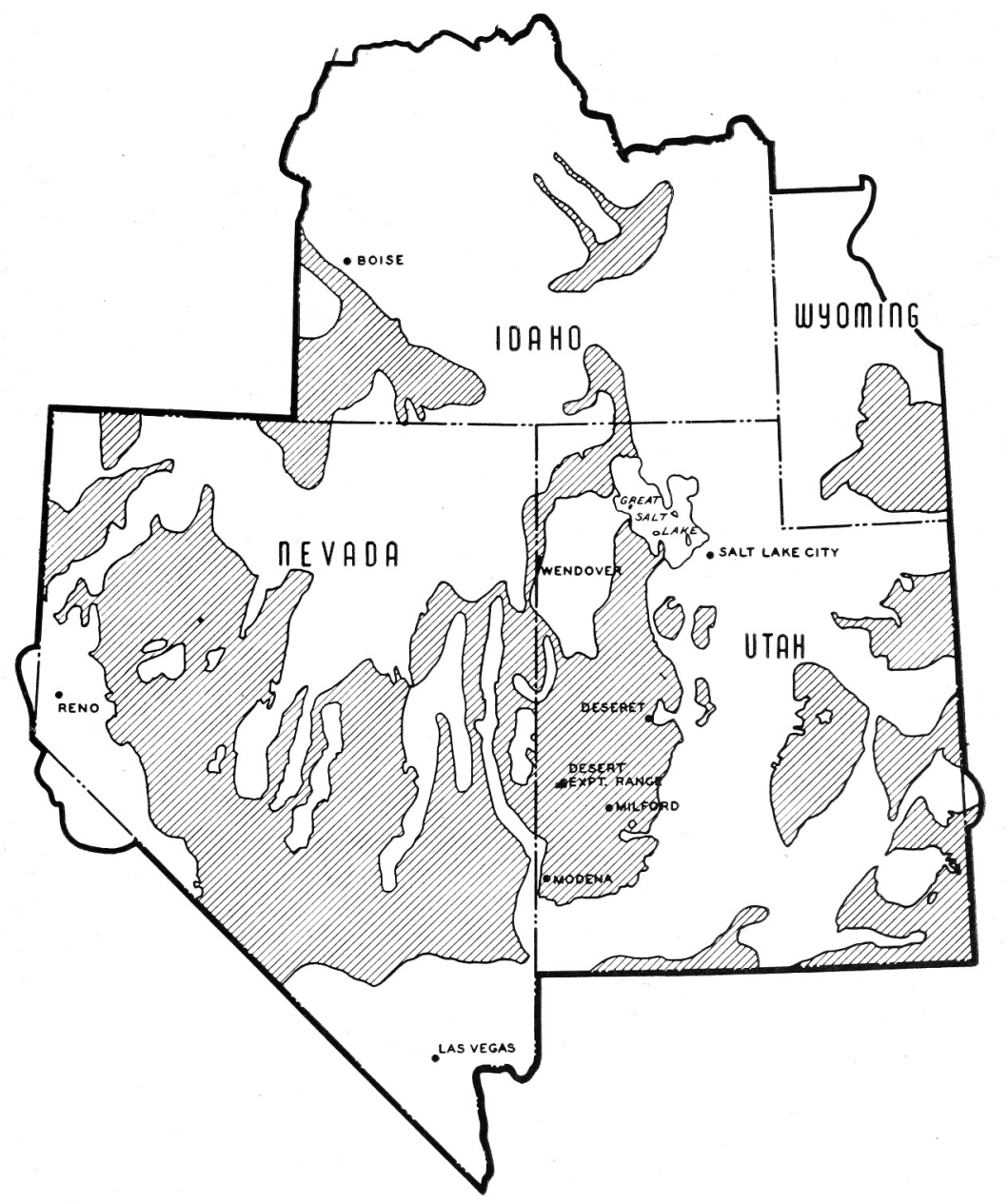

Source: Hutchings and Stewart (1953: 3). 
The rising sheep industry demanded a rather unglamorous labor force to herd and care for large bands of sheep. These sheep workers came largely from the poorer regions of southern Europe, including the Basque Country. In the late nineteenth century, although other immigrant ethnic collectivities also entered this occupation, Basques had become a noticeable and visible group in sheep grazing. At the turn of the twentieth century, when an increasing number of Basque immigrants were arriving in the American West to work as sheepherders, their presence in the public ranges began to disturb the economic interests of the older livestock operators. In other words, Basques were newcomers to an already established grazing empire based largely on cattle. Historian Kevin D. Hatfield said: In the absence of state or federal authority, an intricate web of common law usufruct and proprietary claims to "accustomed ranges" emerged, and confronted the Basques with a contested terrain for establishing their foothold in the New World (2003: 21). By the 1890s, Basque herders roaming freely on public-domain lands with their flocks of several thousand head of sheep had become a growing menace to an established ranching community in Nevada, as well as potential environmental villains for the American Conservation Movement (Gulliford, 2017: 403-6; Saitua, 2017: 195-99) ${ }^{8}$.

In the 1890s, Congress initiated a partial reorganization of the public domain. In response to calls to conserve the nation's forest resources, Congress gave the President the authority to proclaim forest reserves on the public domain, mostly in the Far and Mountain West. Establishment of forest reserves was a first step to conserve and protect water and timber resources. With the passage of the Land Revision Act of 1891, Congress prohibited land entries or private land claims under the land laws of the United States on the designated or proclaimed forest reserve lands. The immediate effects of the Land Revision Act were to close resource use development on these lands (Miller, 2001: 138-39; Rowley, 1985: 4-5, 54).

The reservation of these lands represents the beginning of the American Conservation Movement that formed a major aspect of Progressive Reform politics in the early twentieth century ${ }^{9}$. The newly reserved forestlands presented an opportunity to champion the causes of an emerging Conservation Movement that emphasized the "wise use" of resources based upon a utilitarian doctrine that stressed use for the greatest number, for the greatest good and for the longest period of time (Miller, 2001: 155). The early con-

8. See also SAItUa (2016). For an overview of Basque emigration to America, see DougLass and BILbAo (1975) and Pildain (1984).

9. For an overview of Progressivism's reform agenda, see HAYs (1959), and WIEBE (1965). More recent studies on the federal government's land management policy include PISANI (1996), SKILLEN (2009) and Miller (2012). 
servation measures drew a distinction between legitimate and illegitimate uses of natural resources. Historian Karl Jacoby said: The result has been a narrative drained of all moral complexity, its actors neatly compartmentalized into crusading heroes (conservationists) and small-minded, selfish villains (conservation's opponents). Far beyond natural resource governance, according to Jacoby, conservation was a political and cultural process of stateformation and consolidation $(2001: 3,6)$.

In 1897, Congress further passed the Forest Organic or Forest Use Act. The Act permitted resource use in the reserves, but only under the regulation and supervision of the Department of Interior, from where the original forest reserves were administered. By 1898 and 1899, the Department of Interior and its General Land Office moved to regulate and limit the numbers of stock grazing on the newly-established forest reserves (Steen, 1976: 56-61). In March 1898, Nevada's Reno Weekly Gazette and Stockman informed its grazing community that the federal government opened the forest reserve in California to her starving herds ${ }^{10}$. While forest reserves were proclaimed in California during the 1890s, lands in Nevada would not be reserved for National Forests until after 1905. Since there were no forest reserves or National Forests in Nevada during the decade of the 1890s, free and open range existed even in the valuable high mountain pastures. In the still abundant free open ranges of Nevada, law enforcement was weak or absent, giving opportunity to incidences of violence (Clawson, Venstrom \& Phinney, 1938: 4-6).

During the 1890s, no forest reserves were created in Nevada, a situation that sharply contrasted with its sister state California. In this state, the entrance of government management of renewable natural resources on public-domain lands significantly altered the economics of sheep production. The establishment of national parks and forest reserves in California closed access by sheep graziers to parts of the Sierra. It is well known that in 1891 Captain Abram E. Wood, commander of the Forth Cavalry and first acting superintendent in charge of the troops assigned to protect Yosemite National Park, drove out bands of sheep (Meyerson, 2001: 95-103). Woolgrowers accused the forest reserves and later the National Forests of permitting cattle to graze while excluding sheep. Typically, local groups, especially sheep and wool interests, rallied against grazing use regulations in the new forest reserves (Rowley, 1985: 28-38) ${ }^{11}$.

Early forest rangers were charged with the sometimes challenging task of preventing itinerant herders from entering government forest lands that were now administered un-

10. Reno Weekly Gazette and Stockman, March 31, 1898, p. 2.

11. Conquering the West:The Federal Lands Question. National Wool Grower, 55, January 1965, pp. 87-89; see also RAKESTRAW (1958: 371-82). 
der grazing regulations. Even earlier before the enforced regulations of the National Forests itinerant sheepherders wantonly disregarded any prohibition on their use of forest reserve grazing lands and developed a contempt of any restrictions on the movement of their sheep bands (Echeverria, 1991: 41-58). In the early twentieth century, Charles H. Shinn, an early forest ranger, recalled that sheepmen mocked and ridiculed the authority of the forest rangers. Oftentimes, sheepherders, Basques and others, violated the law and circumvented rangers' mandates. But Shinn complained about the cattle ranchers as well because of their opportunistic stance on the sheep question. Cattle people rushed to endorse the widely held opinions that roving bands of sheep destroyed forest vegetation, reduced water supply, and made for erosion (Shinn, 1907: 590-97).

Some Basque sheep graziers were arrested and served jail time for violating government regulations. On July 21, 1893, the California-ko Eskual Herria (California's Basque Country) informed its euskaldun readership that a Basque sheepherder, Piarres Aintzano, was arrested for trespass on the San Bernardino Forest Reserve with his sheep band ${ }^{12}$. Next day, on Saturday at the morning, Aintzano paid the bail for release. Soon after this, the same day, Aintzano's employer Bertrand Elgart, who was also Basque, was arrested for the same reason. Elgart was released on the following Monday. The editor of the California-ko Eskual Herria blamed the government for arbitrarily imposing restrictions against grazing on the forest reserves. The Basque language newspaper noted that the boundaries of the new forest reserves were not widely known in the Basque grazing communities and offered to provide maps and information on the newly proclaimed reserves in order to prevent these incidents in the future ${ }^{13}$.

While forest reserves were proclaimed in California during the 1890s, lands in Nevada were not reserved for National Forests until after 1905. Since there were no forest reserves in Nevada during the decade of the 1890s, free and open range existed even in the valuable high mountain pastures. In many respects, it became a free-for-all as graziers competed for resources, sometimes violently. In the 1890s, the continued free and open range in Nevada invited sheepmen from California who no longer had access to the extensive forest reserves in that state ${ }^{14}$. In 1894, preservationist John Muir described the invasion of Nevada in his The Mountains of California: Immense numbers of starving sheep and cattle have been driven through them [the Sierra] into Nevada, trampling

12. California-ko Eskual Herria was a weekly newspaper in Basque language published between 1893 and 1898 in the city of Los Angeles (California).

13. California-ko Eskual Herria, July 22, 1893, p. 2.

14. Clawson, Venstrom and Phinney (1938: 4-6). 
the wild gardens and meadows almost out of existence (1907: 96). This situation intensified the competition for forage and water resources on the Nevada ranges.

Unregulated livestock grazing on common land invited crises and conflicts. In the still abundant free open ranges of Nevada, law enforcement was weak or absent giving opportunity to incidence of violence. Confrontations occurred amongst landowning stock operators and nomadic sheep graziers over water rights, trespass, and destruction of forage resources on the common rangelands. Sheepherders, either Basques or others, were easy targets for their opponents or enemies (Hays, 1959: 49-50). In November 1895, for example, two Basque sheepherders were killed at a sheep camp northwest of Pyramid Lake nearWinnemucca Valley, in Nevada, by two ranch hands working for the cattle operation of J. M. Flannigan ${ }^{15}$.

By the early twentieth century, livestock agriculture in Nevada was a major economic activity. In 1900, Edward D. Kelley, Nevada Surveyor General, declared that the livestock industry was one of the most prominent as well as most profitable in the State ${ }^{16}$. However, the itinerant sheep grazing continued to present a threat to larger livestock interests that traditionally operated on the public-domain lands in Nevada (Lane, 1974: 63-74). Between 1890 and 1910, Nevada's legislature responded with the enactment of several branding and trespassing laws in an attempt to give some protection from the roaming sheep bands. But these measures were not sufficient to protect the interests of the older livestock operators ${ }^{17}$. By the turn of the century, problems on the Nevada ranges called for some authority to order the growing tensions between itinerants and landowning stock operators both cattle and sheep owners.

15. Nevada State fournal, November 16, 1895.

16. Biennial Report of the Surveyor-General and State Land Register, State of Nevada, for 1899-1900, Carson City, 1901, p. 7.

17. Statutes of the State of Nevada, Passed at the Sixteenth Session of the Legislature, 1893, Carson City, 1893, pp. 30-1; The Fournal of the Assembly of the Seventeenth Session of the Legislature of the State of Nevada, Carson City, 1895, pp. 103-4; The Fournal of the Assembly of the Eighteenth Session of the Legislature of the State of Nevada, Carson City, 1897, pp. 182-3, 198, 219; The Fournal of the Senate of the Eighteenth Session of the Legislature of the State of Nevada, Carson City, 1897, p. 203; Biennial Report of the Surveyor-General and State Land Register, State of Nevada, for 1899-1900, Carson City, 1901, p. 7; Reports of Cases Determined in the Supreme Court of the State of Nevada, During 1908, vol. 30, Carson City, 1909, pp. 241-44. 


\section{NATIONAL FORESTS, THE SHEEP GRAZING QUESTION, AND THE BASQUES IN NEVADA}

By the beginning of the twentieth century, Nevada still offered good opportunities for open-range stock grazing because of free range and rising agricultural prices. The Surveyor General of Nevada, Edward D. Kelley continued to be optimistic about the livestock industry in his biennial report for the years 1903 and 1904. He declared that the livestock industry was one of the most important and profitable economic sectors in Nevada, and those engaged in it are among the wealthiest people in the State ${ }^{18}$. The increasing arrival, however, of new stock outfits meant more competition for depleted ranges. Although the most productive lands were occupied and controlled by specific livestock and railroad companies, the remaining marginal rangelands still presented opportunities for the expansion of grazing enterprises ${ }^{19}$.

The scarcity of timbered lands in this arid state made it difficult for Nevada to qualify for forest reserve designations. On August 10, 1904, Gifford Pinchot, Chief of the Division of Forestry, US Department of Agriculture, and on behalf of the Public Land Commission, sent a letter to John Sparks, Nevada Governor, asking some questions concerning lands under state ownership and their relation to the open-range public domain ${ }^{20}$. From Carson City, Kelley, State Land Register, replied. The responses reflected how in the early twentieth century, Nevada's public lands largely remained unregulated and unprotected, and none of the reverted lands now owned by the State are timber lands ${ }^{21}$. Only after 1905 with the transfer of forest reserves from the Department of Interior to the Department of Agriculture will National Forests be created in Nevada under the administration of the Forest Service (Lane, 1974: 142).

In February 1905, during the Administration of Theodore Roosevelt (1901-09), the Department of Interior's administrative functions and responsibilities were transferred to

18. Biennial Report of the Surveyor-General and State Land Register, 1903-1904, Carson City, 1905, p. 9.

19. Clawson, Venstrom and Phinney (1938: 8-16).

20. In 1903, President Theodore Roosevelt appointed a Public Land Commission composed by Gifford Pinchot, Frederick H. Newell, and William A. Richards in an attempt to determine the problems affecting the public-domain lands. Report of the Public Lands Commission, With Appendix, 58th Cong., 3d Sess., Doc. no. 189, Washington, DC, 1905, pp. 3-11.

21. Edward D. Kelley, State Land Register, to Gifford Pinchot, August 31, 1904. Biennial Report of the Surveyor-General and State Land Register, 1903-1904, "Questions and Answers", Gifford Pinchot, Secretary of the Commission on the Public Lands, to John Sparks, Governor of Nevada, August 10, 1904, pp. 15-6. 
a newly established agency, Forest Service, within the Department of Agriculture. Gifford Pinchot, friend and adviser of Roosevelt, was appointed Chief Forester for the new agency. At the turn of the century, to Pinchot, grazing was one of the most important economic activities in the forest reserves. In 1905 Pinchot and the Forest Service continued to implement a permit system for grazing that the General Land Office had begun. The preference system persisted into the grazing program undertaken by the Forest Service after the transfer of the reserved forests lands to the Department of Agriculture in 1905. The Forest Service issued a Use Book that defined resource-use regulations under a permit for an allotment. In 1902, the Department of Interior through the Forest Reserve Manual had stated that the Secretary of Interior possessed the authority to restrict any livestock grazing activity with the aim of protecting the forest reserves. The new Forest Service blueprint made similar claims for the Secretary of Agriculture (Miller, 2001: 162-64; Rowley, 1985: 46-59).

The Use Book set out rules on grazing seasons, set numbers of stock, and issued grazing permits based upon property ownership and traditional use criteria. Three classes of grazing permits were available: first, Class A to those owners of ranch properties within or adjacent to the National Forests who customarily grazed stock on lands now within the National Forests; second, Class B for those who possessed property near the National Forests and traditionally grazed stock in these high mountain pastures; and third, Class $\mathrm{C}$ to itinerant graziers who did not own property or a home ranch. The various permits were issued on the basis of this preference criteria. All permits granted were considered grazing privileges not rights by the Forest Service. The preference system favored the first two classes and generally excluded the third or Class C permits. Also, the Forest Service's based its preference system on the concept of commensurate property ownership. The principle of commensurability required graziers to own enough private land to support winter feeding of stock when they must be removed from the National Forests at the end of the season of graze. Forest Service considered these policies the mechanism to defend established landowning ranchers and small homesteads against the intrusion of itinerant sheep graziers (Rowley, 1984: 61-7; 1985: 58-62).

\subsection{Unconventional conditions: the report of Herbert Stabler of 1906}

Forest inspectors went far and wide into Nevada to mark off possible forest reservations. New National Forests in the high mountain ranges meant the extension of grazing regulations in the higher and better watered elevations. From April 1 to May 1, 1906, Herbert O. Stabler, forest assistant, prepared a detailed report based on an examination in the Monitor Range in central Nevada. The title of the report itself anticipated the estab- 
lishment of a new Forest: "A Favorable Report on the Proposed Monitor Forest Reserve, Nevada". It noted forest resources in this part of central Nevada, especially the protection of vegetation, particularly ground cover, to protect water supplies. The report was addressed to the Chief Forester Pinchot, which would serve as a recommendation to President Roosevelt to create a National Forest by Proclamation under the authority granted by the provisions of the 1891 Land Revision $\mathrm{Act}^{22}$.

The proposed Monitor Forest Reserve was located in Eureka and Nye Counties, comprising roughly 450,000 acres. Nonetheless, only one-fourth to one-third of the area was surveyed $^{23}$. The Monitor Range was one of a number of parallel mountain ranges that extend north to south in central Nevada. The valley basins between these mountain ranges were at high elevations between 5,000 and 6,500 feet. According to Stabler, the scarcity of water resources prevailed, but there was an exception in the Reese RiverValley, where there was, in his own words, a continuous stream of water. He also noted the persistence of a severe drought that affected and altered dramatically the ecological and agricultural situation. The condition accelerated the process of range degradation in Nevada's marginal lands: In the other valleys the creeks that flow into them are soon dried up and lost because the soil is very sandy and the gradient slight. In terms of climatic concerns, Stabler stressed that these valleys were characterized by the scarcity of rains and very low temperatures, with considerable snowfalls. He observed that the extremely cold winter temperatures often caused great losses of cattle to the ranchers ${ }^{24}$.

The proposed reserve consisted mostly of pinon and juniper trees, which were located primarily on the base of the mountains. Nonetheless, Stabler noted, the distribution of the forestland tracts was very irregular. There was, in his estimate, 25 per cent to 40 per cent of the area shown as woodland that has no forest on it at all. In places where the stand is good it will yield 4 to 5 cords per acre, but as a whole the type will not average more than 1-1/2 cords per acre. Limber pine is found occasionally but in an inconsiderable quantity. The previous mine development in the Danville Canyon in the southern part of the Mon-

22. San Francisco Federal Records Center, National Archives, LP-Boundaries, General, Toiyabe National Forest, 1906-41, Record Group 95. Herbert O. Stabler, "A Favorable Report on the Proposed Monitor Forest Reserve Nevada", 1906, pp. 2-3.

23. During the nineteenth century and later, most of Nevada was not surveyed into the rectilinear townships and ranges required in the Land Ordinance of 1785. The aridity discouraged or made impossible large direct settlement by American homesteaders in family farms or even in a family ranch tradition. The scattered and almost nonexistent settlement upon the land left most of the lands of Nevada without government survey well into the twentieth century (BIRD, 1975: 27-32; PISANI, 1977: 541-42). See also Gates (1968).

24. H. O. Stabler, "A Favorable Report on the Proposed Monitor Forest Reserve Nevada", 1906, pp. 2-3, Toiyabe National Forest. 
itor range had displayed the problems regarding the scarcity of lumber supply. According to Stabler, nonetheless, a scattering reproduction constantly took place that was enough to replace the older trees. In that respect, he noted that if an area is out clear [cleared out or cut over], or nearly so, a long period is required for the development of a normal stand ${ }^{25}$.

Herbert Stabler explained the importance of water and timber conservation to assure the protection of stock ranching as the main economic activity. Looking to the future, he believed that new mining booms would promote local population growth. The protection of forest resources, especially water supplies, was necessary for future economic development: In that case something could be done toward storing water in some of the canyons and in this way many acres could be irrigated and the towns would furnish a ready market for all products. He added: In no event, however, would a protective forest be a serious consideration [there was no forest], because the greater part of the area really [was] valuable for holding water [possible reservoir sites] ${ }^{26}$. In absence of significant forests to protect water resources, the forest inspector was saying that these lands should be reserved because reservoirs could be constructed on these lands to ensure adequate water supplies.

The report assigned considerable importance to the prevailing economic activities on those lands, which were under consideration for the creation of a new National Forest. In the Monitor range, the forest assistant wrote, there is not alienated agricultural land within the limits of the proposed reserve. Stabler did locate three ranches (two devoted to cattle raising and the other one to sheep) on the western part of the range at the mouth of the creek and outside of the proposed forest. Each of these operations had 10 to 15 acres of irrigated land for hay production and other grassland to secure livestock feed during the winter. In addition, there were other cattle ranches on the west side of the Monitor Valley and on the east side, two other operations devoted to cattle raising as well. While the livestock ranching did not usually depend on a supply of timber, according to the Stabler's report, there were other enterprises in the Monitor range that did. For instance, on the western part of the proposed reserve, there was a pumping plant that supplied the town of Tonopah with water. The plant required about 1,300 cords of wood per year for its pumps. Also, a mining company located at Hannapah depended on a wood supply, but the introduction of coal and electricity helped reduce cord wood consumption. Stabler also noted that Hannapah was a declinining settlement and the existence of a forest reservation would now help the development of new communities ${ }^{27}$.

25. Ibid., p. 4 .

26. Ibid., p. 5.

27. Ibid., p. 5. 
The report paid special attention to the livestock grazing activities in the vicinity. Stabler estimated between 800 to 1,000 cattle and at least $88 \%$ of these livestock were owned in the MonitorValley. On the other hand, he mentioned the case of the Potts sheep ranch, which operated 5,000 head of sheep separated into three bands. Stabler observed that the Monitor range was better suited to sheep than cattle. In recent years, he said, sheep population had increased in this part of the country because sheep generally grazed this mountainous range more efficiently than cattle did. Furthermore, the profitability of sheep supplying the new mining towns in Nevada and a favorable international market had increased demand for sheep products. He observed many cattlemen were considering converting their herds to sheep, although the latest changes in the market were favorable to beef. Stabler explained this process as follows:

The range is better suited for sheep as they do not require as much water as cattle, and can, and do graze in rough, rugged portions of the mountains that cattle can not get to. Sheep have been very profitable of recent years owing to the fact that mining camps in the Toquima range [Nye County, Nevada] have furnished a near-by market for mutton and the drought in Australia has caused wool in this country to sell at a good prices. Ranchers, now ranging nothing but cattle, are seriously considering selling out their cattle and buying sheep. Such a step has been postponed because of the good market now available in the mining camps ${ }^{28}$.

According to this forest assistant, overgrazing in the valleys and in the mountains was adversely affecting the livestock agriculture. In his words, grazing was very poor on the Monitor range with the exception of some extensive areas of white sage or winterfat that made for nutritious grazing, especially in winter ${ }^{29}$. In addition, he made reference to the issues between cattle and sheep ranching in this country. Apparently, to Stabler, there existed a harmony among the local cattle and sheep breeders. The problem was outsiders: The transient sheep question causes hard feeling and is a matter for immediate regulation if a reserve is created. He further noted briefly that the danger of fire in that part of the country was at a minimum level and in case a fire started, he wrote, it rarely spreads because there is no ground cover for the fire to run in. With the growing threat of transient sheep invasions, public sentiment in the community, according to Stabler, was strongly in favor of forest reserves. As he explained, local stockmen saw the creation of a National Forest as a means to protect their own economic interests from itinerant sheep herds. In Stabler's opinion, the creation of a forest reserve would provide future mining towns with timber of all kinds. At the end of the report, considering all the factors, Stabler recommended

\section{Ibid., p. 8.}

29. See winterfat in Young and SPARKS (1985: 60-3). 
the creation of a National Forest in the Monitor range primarily because it would reinforce economic development and enhance the settlement in central Nevada, and furthermore, remove many transient sheep from the range ${ }^{30}$.

\subsection{Mark Woodruff and the National Forests in Nevada}

The beginnings of grazing administration raised constitutional matters. In 1906, the enforcement of the Forest Service policies and particularly the implementation of grazing fees sparked criticism from the livestock community. While most welcomed the new rules ordering the rangelands and excluding the tramp sheepherders, they did not like the imposed grazing fees that the Forest Service said was necessary to pay for its regulatory administration (Steen, 1976: 87, 163-64). Not surprisingly a court challenge against the fee system was not far away. The Eureka Livestock Company took these objections into court. It filed a complaint against: Theodore Roosevelt, President of the United States; James Wilson, Secretary of Agriculture; Gifford Pinchot, first Chief of the Forest Service; and David Barnett, Forest Supervisor in Nevada. The 1908 court case became Eureka Livestock Company versus United States. The Basque sheepman's complaint challenged the constitutionality of the federal government to set aside timber lands as National Forests under an act of Congress in the Monitor range, in central Nevada. In September 1908, the plaintiff argued that no federal agency could set apart the public domain for conservation purposes and restrict access to grazing lands where graziers traditionally operated. According to the Eureka Livestock Company, when the Department of Agriculture established the National Forest in the Monitor Range, the company was grazing about 5,000 sheep divided into two bands. Under the new regulations, the Forest Service denied to the livestock company access to these lands and threatened to confiscate the sheep if the company persisted in grazing there. The plaintiff claimed that these lands were only valuable for agricultural and mineral purposes and had little potential for timber extraction. The claimant considered that these lands should not be included into the National Forest system because they were only suitable for agricultural use and mineral extraction ${ }^{31}$.

30. Stabler, "A Favorable Report on the Proposed Monitor Forest Reserve Nevada”, 1906, pp. 910, Toiyabe National Forest.

31. Anaconda Standard, September 11, 1908, p. 7; San Francisco Call, September 11, 1908, p. 5; Los Angeles Herald, October 9, 1908, p. 1; Reno Evening Gazette, October 9, 1908, p. 8; San Francisco Call, October 9,1908 , p. 5. This was amongst several cases challenging the legitimacy not only of imposing grazing fees, but also the creation of the National Forests themselves. Ultimately, by 1911, with the Light versus United States, 220 US 523 (1911) and Grimaud versus United States, 220 US 506 (1911) cases the US Supreme Court ruled in favor of the legitimacy of the National Forests and their authority to impose grazing fees (STEEN, 1976: 88-9, 163; RowLEY, 1985: 66-8; US Forest Service, Range Management Staff, Court Cases related to Administration of the Range Resource on Lands Admi- 
On November 20, 1907, Mark G. Woodruff, Forest Supervisor in Nevada, sent from Austin (Nevada) to Washington, DC a detailed report about the management of the Toiyabe, Toquima, and Monitor National Forests (see Figure 2). Woodruff made a detailed investigation and gathered data relative to the range conditions in the protected lands. In this grazing report, Woodruff explained in detail the range forage degradation on the forest ranges as a consequence of overgrazing and land abuses. It was a distressing situation:

The Toiyabe range has been badly overgrazed as a whole; the Shoshone range is in fairly good condition; the Desatoya range supplies such a small amount of grazing that it is of no particular consequence; the Toquima range has been abused along the foothills, and the Monitor range has been overgrazed in parts ${ }^{32}$.

To understand the nature of the problem, the report provided first some relevant background information, which summarizes the local grazing development stemming from the prolonged crisis since the winter of 1889-90, with special focus on the expansion of sheep grazing to the detriment of cattle ranching: The sheep men and their flocks have become more numerous, and finally disregarding any and all rights belonging to other range users, the sheep men have encroached even to the fences of the patented lands in the low foot hills. He further noted:

The plan of grazing has been to winter the sheep in the deserts lying to the south of these Forests. As spring comes on the sheep work north to the country lying about thirty miles north of Austin, where the lambing and shearing takes place. As soon as the lambs can travel they are started south again along the top of the Toiyabe range. The best feeding ground is at the head of the north fork of the Reese river and Twin canons. Every flock owner has tried to reach that country first. It is a race from the start. The result has been to literally cut the surface of the Toiyabe range into the sheep trails, the bottoms of which in places are several inches below the roots of the grass and weeds ${ }^{33}$.

Woodruff made the expansion of sheep grazing synonymous with the range problem. The Forester noted that the sheep industry became the leading agricultural economic ac-

nistered by the Forest Service, pp. 9-18).

32. National Records and Archives Administration, College Park, Maryland, Record Group 95, US Forest Service, Files Office of the Chief, Grazing Plans, Mark G. Woodruff to The Forester, Washington, DC, November 20, 1907.

33. Ibid. 
tivity in central Nevada threatening cattle ranching. Woodruff reported how sheep cut the gravelly the soil very badly and noted his efforts to protect ranges against the ravages of thousands of sheep: You will realize more fully what the condition is when I state that in 1906 ninety-six thousand sheep made the trip from the north end to the south end and back to the starting point through the narrow Toiyabe range. He said that he succeeded in stopping 13,400 sheep of a total 63,000 from entering the National Forest. He made an estimate of the total sheep population crossing the National Forest counting the livestock of the operations based primarily on small operations. Roughly half of these companies were owned by Basques ${ }^{34}$.

\section{FIGURE 2}

\section{Range areas in Nevada under consideration for inclusion} in the National Forest System, 1914^

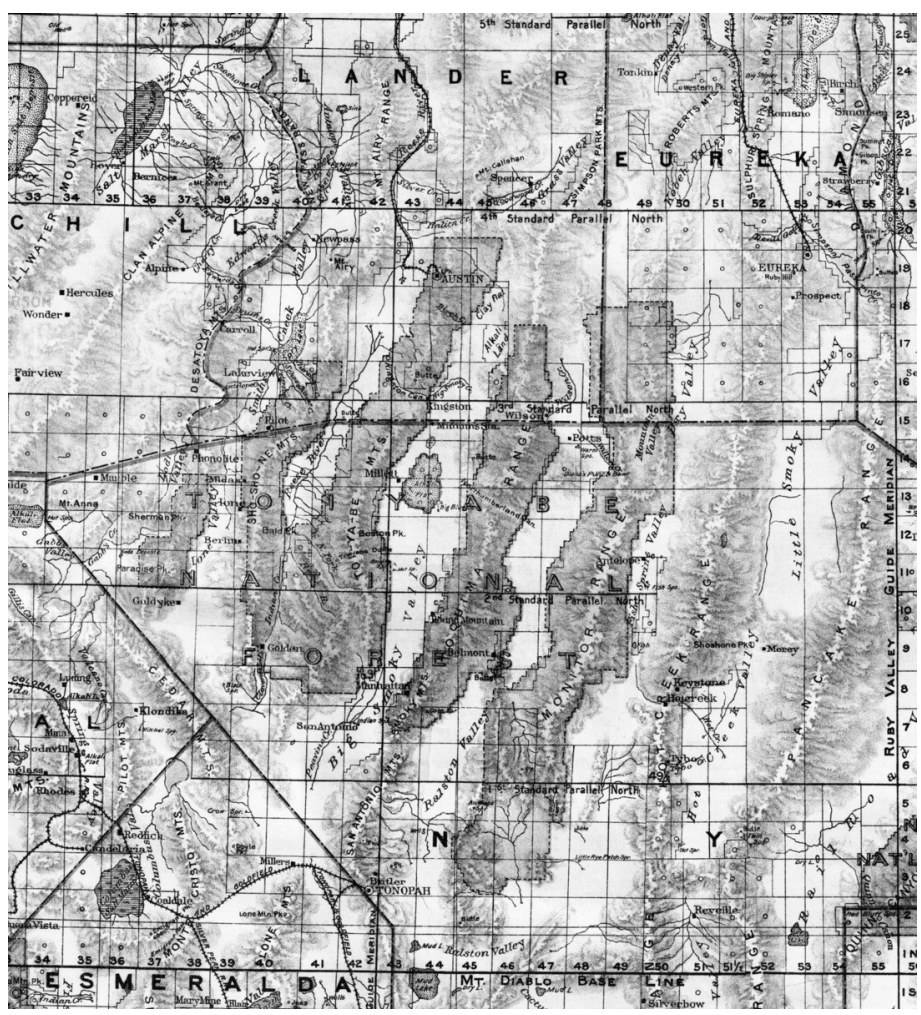

* From State of Nevada. Compiled from the official records of the General Land Office and other sources under the direction of I.P. Berthrong

Source: courtesy of Special Collections, University of Nevada, Reno Libraries.

\section{Ibid.}


Roving sheep bands on Nevada's open ranges, according to Woodruff, were a grave threat and he considered it of vital importance to stop the expansion of these itinerant sheepherders. Woodruff often took action against sheepmen by ordering them away from water sources used by locally owned cattle interests and giving them only a Class $\mathrm{C}$ permit that usually denied them any opportunity for a grazing permit on the National Forests. The following case is an example:

The Toquima range has always been a cattle grazing ground. There is very little water near the north end of the Forest, that which exists being in the narrow canons. The complaint is made that as the sheep work south in the fall they travel the foothills in the district now comprising the National Forest, and when a watering is found they feed in and around the canon until the feed is exhausted and the water polluted to an extent that cattle will not use it. This fall I notified all sheep owners to keep off the Forest area in traveling south and am arranging to station a Guard at Hot Springs to enforce the order.

The Shoshone range has been used for sheep only by Freeman $\mathcal{E}$ Co. of Fallon, Churchill county, Nevada. He owns nothing in or near this National Forest except a possessory claim of 40 acres which he recently acquired. In answer to the question of my grazing circular he stated that his summer range is in the Alpine and Edwards creek mountains, and as this range will be needed by people living near the Forest I am putting him in Class $C^{35}$.

The report continued analyzing the situation in the Monitor range, where again the greatest problem that was threatening the local economy was the open-range sheep industry. Particularly, the east part of the Monitor range, he contended, was highly damaged by the sheep of the Basque-owned Eureka Livestock Company ${ }^{36}$.

While sheep became an issue during the implementation of early forest management, the same held true for wild horses that roamed free and shared pastures with livestock. Along with the poisonous plants and predators, wild horses were main factors that affected greatly to the sheep industry. Wild horses were overrunning the National Forest lands of Nevada and by far were the greatest destroyers of range, Woodruff said, because they trampled the best pastures and water resources threating to the forest ecosystem. He considered wild horses a pest, a nuisance, inbred, worthless and annually destroy forage that would

35. Ibid.

36. Ibid. 
sustain at least 2,500 cattle. Woodruff wanted to remove every wild horse from the ranges of the National Forest ${ }^{37}$.

After analyzing the factors bearing upon cattle livestock grazing, Woodruff considered it necessary to divide the range between sheep and cattle operations. By applying standard scientific criteria (estimating range potential), he intended to reorganize the range in favor of cattle offering the sheep graziers the most rugged terrain since their stock could utilize the more difficult ranges. To put it another way, he wanted to remake an ideal cattle range. He described the situation as follows:

The Forage consists of native bunch grass, weeds and white sage. The canyons break through the front range and then, as a usual thing, spread to the north and south into wide open gulches... The slopes from these gulches to the top of the main range are so steep that cattle will scarcely graze to the top, which is at an altitude of 9,000 to 9,500 feet, and therefore it is considered advisable to district the range so as to admit sheep to the higher country. Some Class $A$ and Class $B$ users are engaged in growing sheep exclusively, so that it seems necessary to divide the range ${ }^{38}$.

Woodruff's plan was to keep both class of stock separate by flagging the lines assigning the best pastures for cattle and keeping sheep in the more inaccessible marginal pastures where sheep could be the more successful grazers. Furthermore, he urged his superior to expend considerable sum of money in the rehabilitation and restoration of water resources to support the varied stock operations ${ }^{39}$.

The land use reclassification had to meet the general plan for managing grazing resources in the National Forest according to the Use Book and the classification of grazing permits. The main goal was always, in Woodruff's words, correct range abuses and to give the degree of protection to those people who are permanent residents, land owners, and of value to the state, that is required in order to build up a prosperous community. He noted that the Forest Service should take a positive position in favor of the home builder as against the transient herder. The conservation of these pastures had to consider only, in his opinion, the interests of the large land owners near the National Forest, who are investing in more lands year by year, who own substantial homes and who are adding to the development of this state ${ }^{40}$.

37. Ibid.

38. Ibid.

39. Ibid.

40. Ibid. 
Woodruff explicitly criticized the Basques who operated in central Nevada. He related the career of two Basque sheepmen Isidoro Sara and John Borda, to whom the Forester gave a Class $\mathrm{C}$ permit:

I find that he [Isidoro Sara] first came into the country as a sheep herder for a man named fensen. That was about 1893. In 1903 he acquired an interest in a band of sheep formerly owned by Dixon $\mathcal{E}$ Stebbins. Then he sold out to George Watt. He then moved to Tonopah, returning here in 1905 and again entering the sheep business. He owns no land, does not own the house in which he lives, and has nothing in common with the residents of this vicinity. He is a Basque, but has taken out his first citizenship papers. I have classed him as Class $C$.

All that has been said for Sara can be said of Fohn Borda, except that he has used the range continuously. He owns nothing aside from sheep and I have put him in Class $C$ in my list of recommendations ${ }^{41}$.

Woodruff saw these people deserving a Class $\mathrm{C}$ permit because they undermined respect for the law, order, and private property. He asserted: Another important reason for so classing men who own no land is that the complaint comes from all directions from the cattle and sheep men alike, that it is the Basque sheep owner and herder who commits the greatest damage to private interests and who utterly refuses to recognize the rights of cattle owners to any range. He emphasized how cattlemen did agree to share the range with sheepmen landowners, but not with the transient operators: The cattle men and ranchmen do not seriously object to dividing the range with local sheep men who own land, but they seriously object to allowing transient flock owners to acquire range rights, or to a recognition of acquired rights, secured by forcing themselves upon the range during recent years. Woodruff observed a broad objection against transients in the local community and welcomed more regulations that could eliminate them. Indeed, the establishment of National Forests in Nevada served to guarantee the economic interests of those who owned land:

Local residents welcome Forest administration solely upon the ground that they need protection in range matters. They feel that they will be driven out of the country unless it is given, and as a matter of fact there is very little reason for the existence of National Forests here aside from water-shed and grazing protection. I strongly believe that the Basques should give way to the man who owns something ${ }^{42}$.

41. Ibid.

42. Ibid. 
Considering the particular case of Nevada and to avoid tramping the cattle range, he suggested sheep and cattle in different grazing districts, and he further recommended that all sheep owners be notified that upon over-running their boundaries a second offense will forfeit their permits ${ }^{43}$.

Woodruff prepared a grazing map showing the range divisions within the Nevada National Forests. He proposed the following livestock restrictions depending on each rangeland conditions for grazing in the year 1908 on three Forests: for the case of the Toiyabe National Forest, Woodruff permitted to enter 8,000 head of cattle and 28,500 head of sheep; for the case of the Monitor National Forest, he allowed 2,000 head of cattle and 10,000 head of sheep; and for the case of the Toquima National Forest, Woodruff allowed to enter 5,000 head of cattle and prohibited the entrance of sheep, establishing a Forest Guard to keep them out. He made a point to notify every sheepmen of these instructions. Many sheepmen used the Toquima range to secure water, while during the fall they went south to the desert and returned north in the spring ${ }^{44}$.

While reducing the number of sheep in the forest ranges, Woodruff recommended to grant a Class A permit to John Spencer \& Co. and gave Class B permits to the following stock operations: The Lander County Live Stock Co., George Watt, and J. A. Miller. In the lower level, or better said, in the Class C, Woodruff recommended the following transient livestock operators to be excluded from the National Forest for the year 1908 because they did not own any land: John W. Freeman Company, John P. Williams, John Laxqua, Pete Lardapeda, John Borda, Pedro Equira, and Isidoro Sara. He made clear that nonowners of land were not welcome:

Fohn W. Freeman Co., Fallon Nevada, sheep, owns nothing in or near any of these National Forests and resides over 100 miles from these ranges.

Fohn P.Williams, Fallon Nevada, and members of his family associated with him in said business, owns nothing in or near any of these National Forests and resides about 100 miles distant.

Fohn Laxqua and Pete Lardapeda, Basques, 5,000 sheep on Toiyabe in 1907, own no land and are not American citizens.

fohn Borda, Basques, 5,000 sheep, owns no land. Used Forest a number of years.

43. Ibid.

44. Ibid. 
Pedro Equira, Basque, owns 4,200 sheep, owns no land, swore under oath that he was not an American citizen. Was allowed in the Forest in 1907 on account of weak lambs.

Isadore Sara, Basque, owns no land in or near National Forest, sold sheep in 1907. Will purchase more sheep and attempt to range them on Toiyabe in 1908, owns no land or home. Has grazed there a number of years ${ }^{45}$.

In the Monitor Forest, the range accommodated both cattle and sheep. In the District 7, he explained that the best right to the sheep range belonged to Mrs. Morrison, who lived near the National Forest on Allison creek. In the same district, the Basque-owned Eureka Livestock Company customarily grazed their sheep there too. Thus, the Forester proposed to admit there two bands of sheep counting of 2,500 head each, owned by both the Morrisons and the Eureka Livestock Company. The Basque sheep company used these pastures for a long time already and in recent years expanded its range use. Since the Eureka Livestock Company was powerful enough to defend its customary rights, especially with their attorney the influential congressman, George A. Barlett (1869-1951), Woodruff proposed to let this Basque owned sheep company to continue operating on the now National Forest lands. Indeed, the Eureka Livestock Company was the only Basque operation with a Class B permit. Briefly, Woodruff's grazing management report proposed to restore the ranges in the National Forests of Nevada by reducing the livestock grazing, favoring cattle, reducing sheep by rejecting Class $\mathrm{C}$ permit holders. All the Basques, except the Eureka Livestock Company, possessed Class C permits ${ }^{46}$.

At the end of the report, Woodruff recommended the sheep grazing season to start on July 1 and ended in October 15. He stipulated the grazing fee for all sheep over six months of age at 8 cents per head. Woodruff expected opposition from ranchmen to the prices, but he thought that those prices were affordable and, he further thought that, it will be better to begin grazing administration by charging good prices than to commence at a low price and be compelled to raise it at a later date. He concluded, however, that the feeling expressed toward National Forest Administration has been almost unanimously cordial. Several people announce that if we can better conditions, they will welcome it, and in one or two cases they openly declare that they are opposed to $i t^{47}$.

45. Ibid.

46. Ibid.

47. Ibid. 
In 1908, Congress moved to put the creation of new National Forests under its authority denying the former power of proclamation to the President. National Forests in Nevada were established by both presidential proclamations and congressional acts. In Nevada, the absence of the forest reservations before 1908 contributed to chaotic competition for range resources and the deterioration of the ranges. With the arrival of the Forest Service grazing regulations and order finally started to take hold in the high mountain pastures of Nevada's mountain ranges. Beyond the boundaries of the National Forests, however, Nevada's ranges remained unregulated and a persisting grazing prob$1 \mathrm{em}{ }^{48}$.

On January 19, 1909, Denver S. Dickerson, Lieutenant and Acting Governor of Nevada, assessed the importance of the conservation laws for Nevada:

One of the most important and far-reaching questions with which the public mind is now occupied is that of the conservation of the natural resources of the country. The President of the United States [Theodore Roosevelt] has wisely appointed a Conservation Commission for the purpose of investigating, compiling data and determining the best method of conserving the Nation's natural resources. Nevada is deeply interested in this subject. Its natural resources, while many, are in a practically undeveloped state. To conserve and develop these resources for the benefit of the present and future generations is an object worthy of the highest endeavor ${ }^{49}$.

In response, Dickerson recommended the creation of a State Conservation Commission, to act in harmony with the National Conservation Commission in the conservation and development of the State's natural resources. He urged that a sufficient fund be set aside to defray the expenses of the Commission ${ }^{50}$.

\subsection{Key Pittman and the enlargement of the National Forest lands in Nevada}

With the establishment of the Forest Service in Nevada, studies began on forage resources in relation to livestock grazing in order to determine an optimum economic use of the

48. Clawson, Venstrom and Phinney (1938: 6); Library University of Nevada, Special Collections. Sack, I., "History of Toiyabe National Forest", 1965, unpublished manuscript.

49. Message of Denver S. Dickerson to the Legislature of 1909, 24th Sess., Appendix to fournals of Senate and Assembly of the Twenty-Fourth Session of the Legislature of the State of Nevada, vol. I, Carson City, 1909, p. 26.

50. Ibid. 
ranges. The Forest Service evaluated and made decisions on range management based on the "carrying capacity" of the ranges as determined by the availability and conditions of range forage. The Forest Service's implementation of grazing fees associated with the issuing of permits on the number of stock grazed generally favored cattle permits, but sheep operations were not excluded, although there were complaints to the contrary. During and after the Great War, state and national representatives became increasingly irritated and frustrated about the uses of the still open rangelands. The Stock Raising Homestead Act of 1916 tried to promote homesteading on the lands with parcels of 640 acres, but only resulted in further monopolization of the lands by large outfits. The amount of land was still too small for successful small homestead ranching.

In the late 1910s, especially after the United States had entered the First World War in the April 1917, the state of Nevada witnessed a remarkable expansion of the livestock industry largely based on the wartime demand for wool, mutton, and beef. High prices for livestock meant prosperity. The Forest Service, for its part, accommodated its regulatory policy to the wartime economic demands and relaxed its protective limits on numbers of stock. High stock prices and almost open admission to National Forest range resources quieted range conflicts at least for a while in rural Nevada. During that period, however, as increasing number of newcomers arrived with new sheep bands to share the resources. At the same time established ranchers, be they sheep people of cattle people, raised concerns about non-citizen immigrants' possessing grazing permits in the National Forests (Rowley, 1999: 247; Rowley, 1985: 67-73; Steen, 1976: 163).

The Great War was followed by a severe depression in the livestock industry in which prices and production dramatically declined. Consequently, many ranchers were forced into bankruptcy. From 1919 to 1922, the postwar crisis was followed by a slow recovery because of a credit crunch which affected negatively on capital investment in the livestock industry characterized by a reduction of competition and increase in risk (Elliott, 1973: 262-63). In 1923, the Nevada Legislature passed a livestock branding act through a system of registration of stock-brands under the supervision of the stock inspector. Although the new state branding law served to discourage sheep itinerancy, still disorder and conflict prevailed in the public grazing lands beyond the Forest Service's National Forests in Nevada ${ }^{51}$. In Grass Valley of central Nevada, on July 9, 1924, Thomas E. Brackney, a prominent rancher of Austin, killed a Basque sheepherder employed by the Sabal Estate and Sheep Company for allegedly trampling his ranch property with his flock ${ }^{52}$.

51. Statutes of the State of Nevada, Thirty-First Session of the Legislature, Carson City, 1923, pp. 2531.

52. Reno Evening Gazette, July 10, 1924, p. 3. 
In the early 1920s, responding to his cattle grazing constituency, Key Pittman, Democratic Senator from Nevada, moved to exclude immigrant sheep operators from using the public grazing lands. His constituents had written Pittman about expanding Forest Service regulations to the public-domain grazing lands outside the National Forests in order to discourage tramp sheep herding. In February 1924, Pittman addressed Chief Forester William B. Greeley advocating the enlargement of the National Forest lands in Nevada in an attempt to have the Forest Service extend its grazing regulations over public-domain range with the intent of further restricting itinerant sheep herding. The Forest Service, however, denied Pittman's request to expand National Forest jurisdiction in Nevada on the ground that the timber within the proposed reserve was not sufficient to warrant conservation, and that such timber did not serve sufficiently to protect a watershed of useable flowing surface water ${ }^{53}$.

Pittman attempted to persuade Greeley to find a legally acceptable way to enlarge the National Forest lands in the state of Nevada. Pittman justified the need to expand the existing regulatory system on economic efficiency grounds:

The use of forest reserves in Nevada for range control has proven of great benefit to the stock growing industry. Range control is essential in Nevada if the range is to be preserved. There is not range control legislation for the unreserved public domain and therefore it becomes important for stock growers to utilize wherever it is beneficial, range control through forest reservations ${ }^{54}$.

Despite Pittman's perseverance, the Forest Service eventually denied the petition of the Senator from Nevada invoking that Nevada's lands were unworthy for further protection. However, the Forest Service empathized with the Nevada's local stock owners' struggles:

53. Library of Congress, Washington, DC, Key Pittman Papers, file Department of Agriculture, box 64, D. Staunton to Key Pittman, March 25, 1914; file Stock Raising Homestead Bill, box 112, Chester A. Laing to Key Pittman, December 8, 1916; file Miscellaneous Correspondence, box 124, T. J. Bell to Key Pittman, April 23, 1917; file Miscellaneous Correspondence, box 124, Key Pittman to T. J. Bell, June 4, 1917; file Forest Service, box 64, Advisory Board of the North Fork Livestock Association to C. E. Favre, November 15, 1917; file Forest Service, box 64, Advisory Board of the North Fork Livestock Association to Key Pittman, February 23, 1918; file Forest Service, box 64, J. H. Clemons to the Forest Service office in Ogden, Utah, March 20, 1918; file Department of Agriculture, box 64, Timothy Murphy to Key Pittman, April 26, 1918; file Grazing Reserves, box 104, Key Pittman to James Dysart, June 2, 1923; file Nevada National Forests, box 108, Key Pittman to William B. Greely, February 21, 1924.

54. Library of Congress, Washington, DC, Key Pittman Papers, Key Pittman to William B. Greely, February 21, 1924. 
During the past ten years, however, transient sheep owners, excluded from other ranges by private acquisition, or otherwise, have come into this region in increasing numbers and have not only deprived the local stock growers of the forage resources upon which they are dependent but, through excessive grazing and improper use of the range, have largely destroyed the grazing value of the lands 55 .

Although the Conservation Movement and private companies shared views toward safeguarding and preserving economic stability, this time, the Forest Service considered unjustifiable the expansion of its lands or more to the point it did not believe it had the lawful authority to do so. Beyond their powers, the Forest Service and the Secretary of Agriculture judged necessary that Congress should enact legislation for constructively managing the use of the public-domain lands for grazing purposes ${ }^{56}$.

Nevada cattle owners became increasingly frustrated over the government inaction concerning the management of the public-domain lands in Nevada. In April 1924, the Secretary-Treasurer of the Quinn Canyon Livestock Association wrote to Pittman complaining about the overgrazing and destruction caused by the sheepherders in the public grazing lands beyond the National Forests. He wanted some form of government control or regulation to stop the trampling bands of sheep:

The grazing of livestock during the summer months in practically all parts of the State is properly taken care of and provided for through the present National Forest areas throughout the State. The spring, fall and winter ranges are not properly taken care of or controlled and as a result these three seasonal ranges are fast becoming denuded and unless some immediate action is taken to place these ranges under some form of Government control the livestock industry of the State will be completely ruined by over-grazing [sic]. The overgrazed condition on our now open public ranges is being brought about principally by the so-called "tramp sheepmen" who drive their flocks into Nevada early in the fall and allow them to remain here until the following spring. The tramp or transient sheepman has absolutely no regard for the welfare of our ranges, his only interest being to avail himself of the maximum results and benefits of our ranges so long as they last.

The condition as briefly outlined above is becoming worse each year and in an attempt to protect our local ranch and stockmen, two petitions have recently been

55. Library of Congress, Washington, DC, Key Pittman Papers, file National Forests, box 108, Leon F. Kneipp to Key Pittman, April 12, 1924.

56. Ibid. 
forwarded to you praying for additions to the White Pine Division of the Nevada National Forest ${ }^{57}$.

Much to the disappointment of cattle ranchers, Pittman could not obtain legislation to permit the expansion of National Forests, and the Forest Service and the Department of Agriculture declined to cooperate with him in the effort. In the 1920s a series of issues disturb the ranching community in Nevada: tramp sheepherders; grazing fees; grazing permits or "privileges"; the attachment or no attachment to ranch property; enhanced ranch values created by grazing permits (Rowley, 1985: 119, 123).

Nevada's US Senator Key Pittman worked tirelessly on the range issues, particularly on the persistent problems affecting the cattle business in Nevada. His early political career was marked by continuous defense of the cattle community and a hostility toward the sheep industry. Pittman's efforts to extend the boundaries of National Forests aimed to undermine the sheep business in Nevada. Furthermore, Pittman's anti-immigrant sentiments fitted well with his fight against the sheep industry that was synonymous with the Basque immigrant community. Basque sheepherders were, in his own words, uprooting the vegetation, breaking down fences, destroying roads, obliterating ranges, defiling the watercourses, and driving the cattle and horses of the farmer off of their natural ranges ${ }^{58}$. Pittman's stand against the Basque-run sheep industry did not gain the expected support in Nevada, and in fact there was a backlash that came to the defense of the Basques as an important community contributing to the economy of Nevada. In time a popular sympathy developed towards Basque immigrant labor in Nevada. By the early 1910s, although still faced with discrimination and stigmatization on the ranges, it can be said that Basque immigrants were settling and integrating into the broader American society of Nevada and other western states (Saitua, 2016: 69-70).

\section{CONCLUSION}

In the late nineteenth century, Nevada became one of the largest range sheep-producing states in the American West. The lack of some authority to regulate grazing on public-domain lands and access to cheap labor to oversee great herds of sheep made Nevada a perfect state to raise meat on the hoof. To put it another way, the land was marginal as well

57. Library of Congress, Washington, DC, Key Pittman Papers, file Nevada National Forests, box 108, F. N. Smith to Key Pittman, April 7, 1924.

58. Nevada Historical Society, Reno, Nevada, Key Pittman Papers, Speech of Hon. Key Pittman, Cong. Rec., 63rd Cong., 1st Sess., August 21, 1913. 
as the labor. As sheep ranching expanded rapidly in Nevada, the Basque Country became an important source of pliable labor to work on the public rangelands as sheepherders. In a context of increased economic competition and social tension on Nevada's ranges, older cattlemen scapegoated Basque workers for all the problems with grazing on public lands. Thus, the Basque presence in Nevada and the vast herds of sheep they tended not only created an agenda for conflict that marked the Nevada range struggles, but also, like other transient sheepherders, influenced the Forest Service decisions about who should graze and have access to high mountain pastures.

In 1905, with the coming of federal land management to portions of the public domain in Nevada (mountain pastures), the Forest Service tried to limit or exclude large itinerant sheepherding from the lands it administered. The still-abundant public grazing lands beyond the Forest Service's National Forests within the state, however, were anything but ordered. The itinerant sheep herds still moved into the basin and rangelands each season, and some overwintered on white sage or winter fat. Expanding Forest Service range regulations to the public-domain grazing lands outside the National Forests held the solution to halting sheep itinerancy and offered the prospect of more stability on the range. While cattle grazing interests were generally pleased with Forest Service grazing policies, they were displeased with the lack of attention to grazing regulations and indifference to the chaotic grazing situation on the open range lands of Nevada beyond Forest Service boundaries.

On behalf of his cattle-ranching constituency, Senator Key Pittman attempted to put forth solutions and even opposition to the presence of itinerant Basque sheepherders on the Nevada ranges. Pittman lobbied to expand the government's role in environmental regulation as a means of keeping itinerant stock from productive mountain pastures desired by local ranchers. But he had little success and local livestock operators continued complaining about the chaotic grazing conditions on the public domain. Year after year, they continued to blame the transient stock operations and their Basque immigrant herders for scavenging the scarce forage. It was not until 1934 that the federal government became actively involved in regulating livestock grazing on public-domain lands with the passage of the Taylor Grazing Act.

\section{ACKNOWLEDGEMENTS}

I sincerely thank the anonymous reviewers for their constructive comments and the editors of Historia Agraria. 


\section{REFERENCES}

Adams, R. (1916). Public Range Lands: A New Policy Needed. American fournal of Sociology, 22 (3), 324-51.

Baden, J. A. \& Snow, D. (Eds.) (1997). The Next West: Public Lands, Community, and Economy in the American West. Washington, DC: Island Press.

BIRD, J.W. (1975). A History of Water Rights in Nevada. Nevada Historical Society Quarterly, 18 (1), 27-32.

Clawson, M., Venstrom, C. \& Phinney, T. D. (1938). Range Lands of Northeastern Nevada:Their Proper and Profitable Use: A Progress Report. Washington, DC: US Department of Agriculture.

Cronon, W. (1991). Nature's Metropolis: Chicago and the Great West. New York: W. W. Norton.

Davis, S. P. (1913). The History of Nevada. Vol. 1. Reno: Elms.

Douglass, W. A. \& Bilbao, J. (1975). Amerikanuak: Basques in the New World. Reno: University of Nevada Press.

Eastman, C. \& Gray, J. (1987). Community Grazing: Practice and Potential in New Mexico. Albuquerque: University of New Mexico.

ECHEVERRIA, J. (1991). Basque "Tramp Herders" on Forbidden Ground: Early Grazing Controversies in California's National Reserves. Locus, 4 (1), 41-58.

Elliott, R. R. (1973). History of Nevada. Lincoln: University of Nebraska Press.

Gates, P. W. (1968). History of Public Land Law Development. Washington, DC: Government Printing Office.

Gulliford, A. (2017). Aldo Leopold, Estella Bergere, Mia Casita and Sheepherding in New Mexico and Colorado. Natural Resources fournal, 57 (2), 395-427.

HATFIELD, K. D. (2003). "We were not Tramp Sheepmen": Resistance and Identity in the Oregon Basque Community, Accustomed Range Rights, and the Taylor Grazing Act, 1890-1955. Doctoral dissertation. Eugene: University of Oregon.

Hays, S. P. (1959). Conservation and the Gospel of Efficiency: The Progressive Conservation Movement, 1890-1920. Cambridge: Harvard University Press.

Hutchings, S. S. \& Stewart, G. (1953). Increasing ForageYields and Sheep Production on Intermountain Winter Ranges. Washington, DC: US Department of Agriculture. (Circular, 925).

JACOBY, K. (2001). Crimes against Nature: Squatters, Poachers, Thieves, and the Hidden History of American Conservation. Berkeley: University of California Press.

Lane, R. H. (1974). The Cultural Ecology of Sheep Nomadism: Northeastern Nevada, 1870-1972. Doctoral dissertation. New Haven:Yale University.

MERRIAM, W. R. (Dir.) (1902). Census Reports: Twelfth Census of the United States, Taken in the Year 1900.V: Agriculture: Farms, Live Stock, and Animal Products. Part I (pp. 
704, 708). Washington, DC: United States Census Office.

MeYerson, H. (2001). Nature's Army:When Soldiers fought forYosemite. Lawrence: University Press of Kansas.

Miller, C. (2001). Gifford Pinchot and the Making of Modern Environmentalism. Washington, DC: Island Press/Shearwater Books.

Miller, C. (2012). Public Lands, Public Debates: A Century of Controversy. Corvallis: Oregon State University Press.

MuIR, J. (1907 [1894]). The Mountains of California. New York: The Century Co.

PildAIN, M. P. (1984). Ir a América: La emigración vasca a América (Guipúzcoa 18401870). San Sebastián: Sociedad Guipuzcoana de Ediciones y Publicaciones.

PisAni, D. J. (1977). Federal Reclamation and Water Rights in Nevada. Agricultural History, 51 (3), 540-58.

Pisani, D. J. (1996). Water, Land, and Law in the West:The Limits of Public Policy, 18501920. Lawrence: University Press of Kansas.

Rakestraw, L. (1958). Sheep Grazing in the Cascade Range: John Minto vs. John Muir. Pacific Historical Review, 27 (4), 371-82.

Rowley, W. D. (1984). Privilege vs. Right: Livestock Grazing in U.S. Government Forests. In H. K. STEEN (Ed.), History of Sustained-Yield Forestry: A Symposium (pp. 61-7). Durham: Forest History Society.

Rowley, W. D. (1985). U.S. Forest Service Grazing and Rangelands: A History. College Station: Texas A\&M University Press.

Rowley, W. D. (1996). Reclaiming the Arid West: The Career of Francis G. Newlands. Bloomington: Indiana University Press.

RowLEy, W. D. (1999). Historical Considerations in the Development of Range Science. In H. K. STEEN (Ed.), Forest andWildlife Science in America: A History (pp. 230-60). Durham: Forest History Society.

Rowley, W. D. (2000). From Open Range to Closed Range on the Public Lands. In W. G. Robbins \& J. C. Foster (Eds.), Land in the American West: Private Claims and the Common Good (pp. 96-118). Seattle: University of Washington Press.

SAITUA, I. (2016). Becoming Herders: Basque Immigration, Labor, and Settlement in Nevada, 1880-1910. Montana: The Magazine of Western History, 66 (4), 58-70.

SAITUA, I. (2017). Los pastores vascos y la guerra de las praderas: Inmigración vasca, industria ganadera y conflictos por las tierras federales en el estado de Nevada, 18901934. Cuadernos de Historia Contemporánea, (39), 191-211.

SHINN, C. H. (1907). Work in a National Forest. Forestry and Irrigation, (13), 590-97.

SkILLEN, J. R. (2009). The Nation's Largest Landlord:The Bureau of Land Management in the American West. Lawrence: University Press of Kansas.

STEEN, H. K. (1976). The U.S. Forest Service: A History. Seattle: University of Washington Press. 
White, R. (1991). "It's Your Misfortune and None of My Own": A Nerw History of the American West. Norman: University of Oklahoma Press.

WiEBE, R. H. (1965). The Search for Order, 1877-1920. New York: Hill and Wang.

Young, J. A. \& SPARKs, B. A. (1985). Cattle in the Cold Desert. Logan: Utah State University Press. 